\title{
Emergence of West Nile virus lineage 2 in Europe: a review on the introduction and spread of a mosquito-borne disease
}

\author{
Luis M. Hernández-Triana ${ }^{1}$, Claire L. Jeffries ${ }^{1}$, Karen L. Mansfield ${ }^{1}$, George Carnell ${ }^{2}$, Anthony R. Fooks ${ }^{1,3}$ and \\ Nicholas Johnson ${ }^{1}$ *
}

${ }^{1}$ Wildlife Zoonoses and Vector-Borne Diseases Research Group, Animal and Plant Health Agency, Addlestone, UK

2 London School of Hygiene and Tropical Medicine, London, UK

${ }^{3}$ Department of Clinical Infection, University of Liverpool, Liverpool, UK

\section{Edited by:}

A. Paulo Gouveia Almeida, Universidade Nova de Lisboa, Portugal

\section{Reviewed by:}

Yingchen Wang, University of North

Carolina Greensboro, USA

Lin Wang, The University of Hong

Kong, China

A. Paulo Gouveia Almeida,

Universidade Nova de Lisboa,

Portugal

${ }^{*}$ Correspondence:

Nicholas Johnson, Animal and Plant Health Agency (APHA), Woodham

Lane, Addlestone, Surrey

KT15 3NB, UK

e-mail: nick.johnson@apha.gsi.gov.uk
West Nile virus (WNV) is transmitted by mosquitoes and causes fever and encephalitis in humans, equines, and occasionally wild birds. The virus was first isolated in sub-Saharan Africa where it is endemic. WNV lineage 1 has been responsible for repeated disease outbreaks in the countries of the Mediterranean basin over the past 50 years. This lineage was also introduced into North America in 1999 causing widespread human, equine, and avian mortality. WNV lineage 2, the first WNV lineage to be isolated, was believed to be restricted to sub-Saharan Africa causing a relatively mild fever in humans. However, in 2004, an investigation in Hungary of a case of encephalitis in a wild goshawk (Accipiter gentiles) resulted in the isolation of WNV lineage 2. During the summer of 2004, and in subsequent years, the virus appeared to spread locally throughout Hungary and into neighboring Austria. Subsequently, WNV lineage 2 emerged in Greece in 2010 and in Italy in 2011, involving outbreaks on the Italian mainland and Sardinia. Further spread through the Balkan countries is also suspected. Whole genome sequencing has confirmed that the virus responsible for the outbreaks in Greece and Italy was almost identical to that isolated in Hungary. However, unlike the outbreaks in Hungary, the burden of disease in Mediterranean countries has fallen upon the human population with numerous cases of West Nile fever and a relatively higher mortality rate than in previous outbreaks. The emergence of WNV lineage 2 in Europe, its over-wintering and subsequent spread over large distances illustrates the repeated threat of emerging mosquito-borne diseases. This article will review the emergence of WNV lineage 2 in Europe; consider the pathways for virus spread and the public health implications for the continent.

Keywords: West Nile virus, lineage, emergence, encephalitis, Europe

\section{INTRODUCTION}

In recent years, arthropod-borne viruses have shown an increasing ability to spread beyond the areas, which had been considered to be their established geographic ranges. A number of factors are driving this process including bird migration, increasing global trade, and the movement of vector species (1). This range expansion threatens public and livestock health. Examples of viruses that have emerged in Europe and which are pathogenic for livestock include bluetongue virus (2) and most recently Schmallenberg virus (3). Such disease outbreaks incur both economic and animal health costs that threaten the livestock industry. Other emerging viruses are zoonotic, and the repeated emergence of West Nile virus (WNV) in Europe is a particular example of one such range expansion (4). The ability to detect and respond to emerging disease outbreaks, through rapid pathogen testing and host-specific serological assays, is a key component for disease response. This review considers the emergence of WNV lineage 2 in Europe as an example of the threat to public and livestock health from emerging zoonoses.
West Nile virus is classified within the genus Flavivirus, family Flaviviridae, and is phylogenetically and antigenically related to Japanese encephalitis virus. The virus was first isolated from the blood of a woman suffering a febrile illness in the West Nile district of Uganda (5). This first isolate is now believed to belong to lineage 2 suggesting its early zoonotic potential. Subsequent studies made further isolations of WNV from human sera in Egypt (6), and from birds and mosquitoes (7). This established that mosquitoes were the likely virus vector and through blood-feeding on birds, the virus was maintained in an endemic cycle. Early phylogenetic studies (discussed in more detail in subsequent sections) demonstrated that there are two major lineages, both present in Africa (8). Subsequent events including the emergence of WNV in North America, its spread throughout the western hemisphere, and repeated outbreaks in Europe suggest that WNV has the largest distribution of any arthropod-borne virus. In Africa, WNV is endemic and widely distributed. Human cases have been sporadic, but environmental conditions favoring mosquitoes, such as high diurnal temperatures or frequent rainfall, have led to large epidemics (9). One such 
episode in the Karoo region of South Africa in 1974 involved tens of thousands of human infections. Currently, approximately 5-15 human cases are confirmed each year in South Africa, however, only a small proportion of cases undergo laboratory investigation, so this may be a considerable underestimate of the actual number of infections (9). In horses and birds, serology studies have demonstrated a high seroprevalence of WNV infection in southern Africa $(10,11)$.

Annual late-summer outbreaks of WNV are now a regular occurrence in European countries that border the Mediterranean Sea and the virus is now considered endemic in some regions (12, 13). Most outbreaks have been identified as WNV lineage 1 and were closely related to outbreaks in Israel and North America (14). This lineage has also been responsible for deaths in humans, horses, and avian species. Strikingly, in Africa, where lineage 2 predominates, relatively few cases of neurological disease are reported, whereas in North America and Europe, numerous human and equine cases have occurred, leading to the suggestion that lineage 1 strains had increased pathogenicity, while lineage 2 strains were of low virulence (9). However, experimental studies in mice (15) and case reports $(16,17)$, have demonstrated that both WNV lineages have the ability to cause zoonotic disease, with the potential for fatal neuroinvasive disease. This has been realized fully with repeated outbreaks of West Nile fever in Greece since 2010, caused by WNV lineage 2, resulting in hundreds of human cases of West Nile neurological disease (WNND) (18).

\section{EMERGENCE OF WNV LINEAGE 2 IN EUROPE}

The first WNV isolated in 1937 in Uganda has since been shown to be a lineage 2 isolate, and for many years this lineage was believed to be restricted to sub-Saharan Africa (5). Until the early 2000s, WNV infections beyond Africa, including its emergence in North America, and Kunjin virus in Australia, were caused by viruses within lineage 1 (19). This included a number of outbreaks in Europe and countries around the Mediterranean Basin (12). Outbreaks of West Nile disease were recorded in Algeria (1994), Morocco and Romania (1996), Tunisia (1997), Italy (1998), Israel and Russia (1999), and France (2000). Detailed phylogenetic analysis of viruses isolated from these outbreaks suggested that those around the western Mediterranean were caused by a single strain, referred to as the WMed subtype, and that this was a single introduction of virus that overwintered over a number of years (20). It was conjectured that this sub-lineage was transferred between Mediterranean countries by viremic birds, leading to the initiation of new outbreaks. A second closely related sub-lineage included viruses isolated from Romania and Russia, and a more divergent sublineage was responsible for outbreaks in Israel and North America. Each sub-lineage likely represents a separate introduction of $\mathrm{WNV}$ into Europe from Africa.

West Nile lineage 2 was first detected in Europe in 2004 with its isolation from the brain of a goshawk (Accipiter gentiles) in Hungary (21). A human case of WNV lineage 2 infection was retrospectively confirmed to have occurred in Russia in the same year (22). Subsequent surveillance between 2004 and 2009 of dead birds of prey, especially in goshawks, led to repeated isolations of the virus across Hungary (23). The species nests and thrives in areas of deciduous and coniferous forests and so would be targeted by ornithophilic Culex pipiens complex mosquitoes, the main transmitters of WNV in Europe. The prevalence of infection in the northern goshawk could also result from oral transmission as this species preys on other birds, particularly pigeons. Local spread resulted in WNV infection of raptors in Austria (24). Subsequent outbreaks have occurred in a number of other European countries including Austria, Greece, Romania, Serbia, and Italy (Table 1; Figure 1).

The outbreak in Greece has been particularly severe. The virus was first detected in 2010 (32) in Northern Greece and developed, in contrast to the emergence in Hungary, into a large human epidemic. The majority of cases were reported west of the city of Thessaloniki, between the rivers Axios and Aliakmonas. Retrospective serology suggests that this virus, or a related one, had been circulating in Greece for some years prior to the first human cases of WN fever (WNF) (33). However, this was at a low level, $<1 \%$ seropositivity, and was not accompanied by reports of disease. The first case in 2010 occurred in early July and incidence peaked in mid-August. The last cases occurred in early October. In total, 262 patients were recorded, with 65 classified as West Nile fever and 197 suffered neurological disease, of which 33 died (34). Age profiling demonstrated that the elderly were most at risk of disease, particularly those over 70 years of age, and risk was further increased if the individual had an existing medical condition such as hypertension, heart disease, or diabetes. Subsequent surveillance isolated WNV lineage 2 from mosquitoes (35), giving rise to the Nea Santa-Greece 2010 strain, and from wild resident birds (36). Epidemics of WNV lineage 2 have occurred during the late summer in Greece in both 2011 and 2012. Further sequencing of viruses detected in humans has confirmed that the same virus strain is present in both humans and wildlife and has been present in each subsequent year, suggesting endemic persistence in Greece (37). This strain appears to cause disease in humans and wild avian species with relatively few confirmed reports of disease in equine species.

West Nile lineage 2 emerged in Italy in 2011, the year after the first detection in Greece. The first reported case occurred in a man in his late 50s in the coastal town of Ancona on the Adriatic Sea (27). The patient reported symptoms of malaise and

\section{Table 1 | Information on confirmed outbreaks of WNV lineage 2 in Europe between 2004 and 2013}

\begin{tabular}{llll}
\hline Country & Year & Species affected & Reference \\
\hline Russia & 2004 & Human & $(22)$ \\
Hungary & $2004-2008$ & Wild birds, sheep, horses, & $(21,23)$ \\
& & human & \\
Austria & 2008 & Wild birds & $(24)$ \\
Greece & 2010 & Human, wild birds, mosquitoes & $(25,26)$ \\
Romania & 2010 & Human & \\
Russia & 2011 & Human & $(22)$ \\
Italy & 2011 & Human, wild birds, mosquitoes & $(27,28)$ \\
Italy (Sardinia) & 2012 & Human & $(29-31)$ \\
Serbia & 2012 & Human & \\
Italy & 2013 & Human &
\end{tabular}




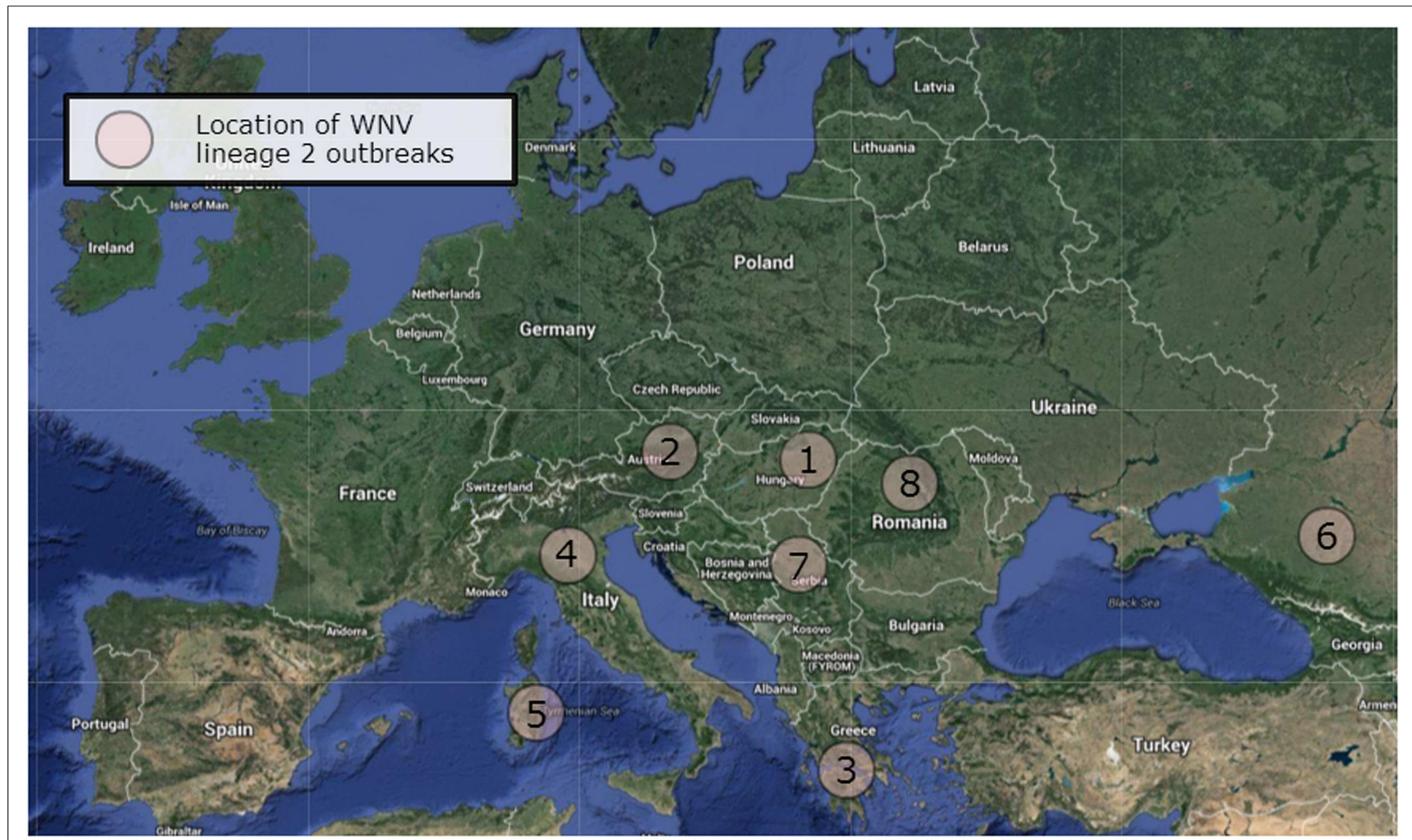

FIGURE 1 |West Nile virus lineage 2 outbreaks in Europe. The outbreaks occurred in Hungary (1), Austria (2), Greece (3), Italy (4), Sardinia (5), Russia (6), Serbia (7), and Romania (8). Map data: Google maps.

fever early in September, and was admitted to hospital. With the patient reporting no history of travel outside of Italy, this was considered an autochthonous case. Shortly after this, six cases of neurological disease due to WNV lineage 2 were reported in Sardinia between September and October, 2011 (28). Mosquito surveillance for WNV detected lineage 2 in $C x$. pipiens mosquito pools and in a collared dove (Streptopelia decaocto) in northern Italy, where lineage 1 has been endemic since 2008 (38). Detections of WNV lineage 2 in Italy have continued in subsequent years, and have included further human cases $(29,31)$. As in Greece, instances of WNV infection in horses in Italy are rare.

West Nile fever was detected in humans in Romania in 2010 and Serbia in 2012. In Romania 57 cases were reported, 54 with neuroinvasive disease (26). In Serbia, 58 patients were confirmed infected (30). Of these, 52 developed neuroinvasive disease and 9 died. Virus isolation and phylogenetic analysis confirmed that both outbreaks were due to WNV lineage $2(26,39)$.

There is currently no vaccine against WNV licensed for human use, and although WNV lineage 2 has not been detected in countries in northern Europe, travelers to affected areas during the periods of vector activity are at risk of infection. This was illustrated by a human case of WNV infection in a 73 years-old Belgian woman who was visiting Greece in the summer of 2012 (40). Following her return to Belgium, samples of serum and cerebrospinal fluid were both positive for WNV IgM and IgG. The serum sample, taken 29 days after development of fever, was positive for $\mathrm{WNV}$ by real-time RT-PCR. A 116 base pair sequence derived from the amplicon was highly suggestive of the presence of WNV lineage 2.

Bird migration has been considered one of the major drivers for translocation of WNV (41-43). The emergence of WNV lineage 2 in Hungary followed by dissemination, both locally and to countries to the south could have resulted from translocation through infected bird movements. Two of the regions where the virus has emerged are dominated by wetland areas, namely the Po Delta in north-east Italy and the Aliakmonas Delta in northern Greece (44). Such areas attract migrating birds moving north from Africa and then returning south again from breeding grounds in central Europe. These areas are also associated with abundant populations of $C x$. pipiens complex mosquitoes. Surveillance in these areas has detected WNV in pools of $C x$. pipiens, and to a lesser extent Cx. modestus (45). This could drive the spread of WNV to indigenous bird species and eventually lead to spill-over infection in humans and horses. This coalescence of events, bird migration, landing periods in wetland areas, and peak vector abundance are needed to stimulate emergence, hence human cases tend to occur in late summer. The repeated emergence of WNV lineage 2 over subsequent summers suggests that over-wintering is occurring, supported mainly by phylogenetic evidence (20), although this is by no means conclusive as local re-introductions could give the same result. If over-wintering is occurring then this would likely be through infected adult females, the primary means of survival of Culex mosquitoes from 1 year to the next. The prevalence of 
virus within the population would gradually increase through the subsequent summer, although always remaining at low levels relative to the total population of mosquitoes, but triggering spill-over infection in humans during late summer.

\section{DISEASE CAUSED BY WNV LINEAGE 2 IN EUROPE}

West Nile virus infection is typically asymptomatic. However, a febrile self-limiting illness is reported in around 20\% of infected humans and is associated with headaches, myalgia, nausea, vomiting, and chills. A papular rash is reported in some cases, but generally symptoms resolve within 7 days (46-48). In approximately $1 \%$ of cases, WNV will enter the central nervous system, infecting neurons and cause neuroinvasive disease $(49,50)$. Neurological forms are varied and can include encephalitis, meningitis, meningoencephalitis, or acute flaccid paralysis (49). Symptoms are exacerbated by old age and immunosuppression. A follow-up study from the 2010 Greece epidemic reported anorexia, muscle weakness, memory loss, and depression to be the most common sequelae in a group of elderly patients who suffered from WNND. Only $31.8 \%$ (7/22) patients recovered fully (48-50).

Equines have been reported to be susceptible to lineage 2 strains, with an increased risk of developing WNND. Clinical signs in horses include ataxia, weakened limbs, paresis, complete paralysis, seizures, chewing, partial blindness, and jaundice/hepatitis (16).

Lineage 2 has been reported with varying mortality across the affected regions. The reasons for this may be linked to the previously characterized threonine 249 to proline (T249P) substitution within the NS3 gene, which was present in WNV isolates responsible for the Greek outbreak but not the Hungarian or Italian isolates $(16,51)$. However, an Italian strain identical to the Nea SantaGreece 2010 strain (with T249P) was reported from the Veneto region of Italy, although there has been an absence of human disease as had been observed in Greece $(25,52)$. The Romanian outbreak of WNV lineage 2 in 2010 had an $8.8 \%$ fatality rate with 57 cases of WNND compared to a previous outbreak of WNV lineage 1 in 1996, which had a 4.4\% fatality rate.

\section{PHYLOGENY OF WNV LINEAGE 2 AND STRAIN VARIATION}

West Nile virus has a single-stranded RNA genome of approximately $11 \mathrm{~kb}$ in length. The genome encodes three structural proteins and seven non-structural proteins. A large number of complete WNV genomes have now been sequenced and can be used for phylogenetic comparison with emerging viruses. This has greatly assisted in the investigation of the likely origins of WNV emergence. The 2004 lineage $2 \mathrm{WNV}$ strain was isolated from a wild goshawk (Accipiter gentiles) in Hungary, and the genomic sequence of this isolate demonstrated closest homology with a group of southern African strains (53). The introduction of WNV lineage 2 into the wetlands of Hungary could have occurred through migratory birds that had become infected in Africa and remained sufficiently viremic during migration to infect mosquitoes in Europe on arrival (23). However, the goshawk is not considered a migratory bird, suggesting that this African lineage 2 strain must have been transmitted by local mosquitoes prior to detection in 2004.

Genetic characterization of the lineage 2 strain detected in Greece confirmed that it was most closely related to the strain that had previously emerged in Hungary (25). Similarly, strains detected in Serbia in 2012 were most closely related to strains previously identified in Greece, Hungary, and Italy (39). The strains detected in Italy in 2013 show closest homology with lineage 2 strains isolated in Italy in 2011 and Austria in 2008 (27). These observations suggest that the spread of lineage 2 throughout Europe was due to spread of the 2004 Hungarian strain, rather than from separate incursions via migratory birds from Africa. Migratory birds could also have played a role in the spread of lineage $2 \mathrm{WNV}$ in Europe during the southerly migration. During autumn, turtle doves (Streptopelia turtur) migrate from breeding areas in central Europe to wintering areas in Africa, and serological studies on individual birds on their arrival in resting areas of Greece suggest that they were exposed to WNV lineage 2 in the area of origin in central Europe, and may constitute a candidate for introduction of lineage 2 strains from central Europe to Greece (37).

The mutation T249P within non-structural protein 3 (NS3) of Greek lineage 2 strains is similar to that observed in neuroinvasive lineage 1 isolates (51), while analysis of Italian strains isolated in 2013 has identified a number of amino acid substitutions including E638K and D831G within the NS5 protein (51). Figure 2 highlights the relationship between lineage 2 strains detected in Europe, and the southern African strains from which they may have originated. The isolates used for phylogenetic analysis are detailed in Table 2. The figure demonstrates the close homology between strains from Italy, Austria, Greece, Serbia, and Hungary (marked by a bracket), with clear divergence between these strains and strains from Africa and Russia, suggesting that lineage $2 \mathrm{WNV}$ might now circulate in a separate enzootic cycle within Europe. A number of these viruses

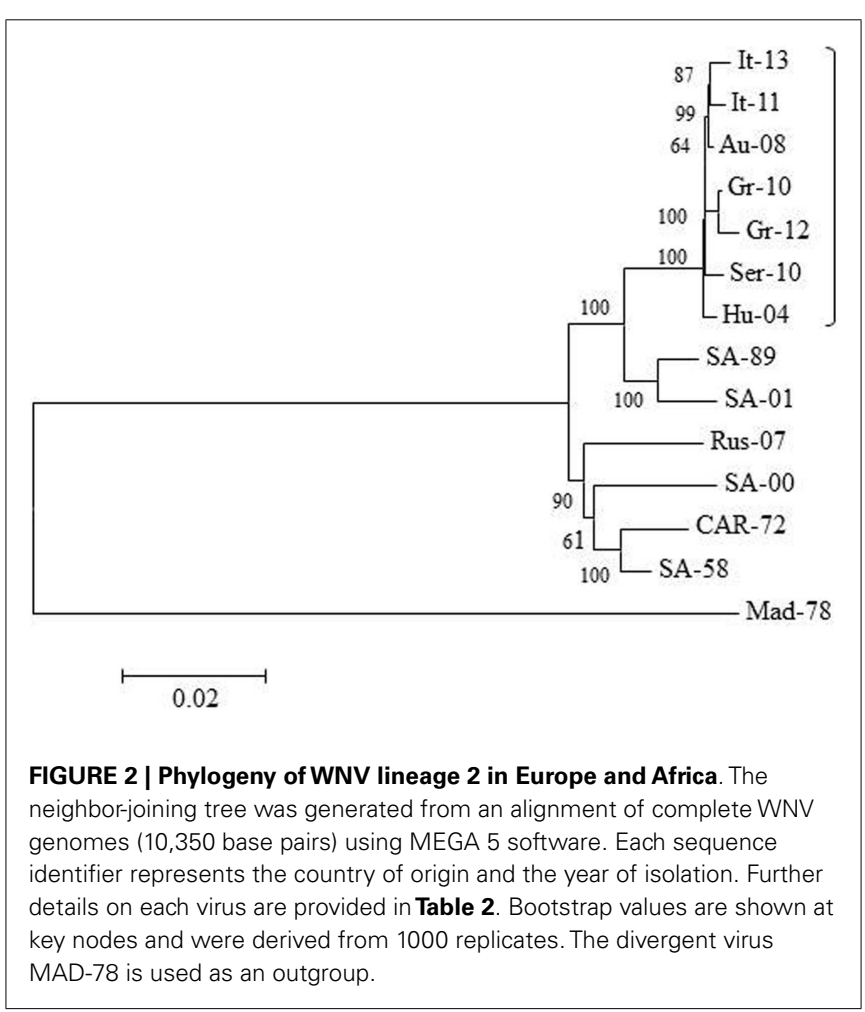


Table 2 | Details of WNV lineage 2 sequences used for phylogenetic analysis in Figure 2.

\begin{tabular}{|c|c|c|c|c|c|}
\hline Sequence ID & GenBank accession no. & Original ID & Species & Country & Year \\
\hline $\mathrm{Hu}-04$ & DQ116961 & Goshawk-Hungary/04 & Accipiter gentilis & Hungary & 2004 \\
\hline Gr-10 & HQ537483 & Nea Santa-Greece 2010 & Culex pipiens & Greece & 2010 \\
\hline Gr-12 & KF179639 & Greece/2012/Kavala.39.1 & Human & Greece & 2012 \\
\hline $\mid t-13$ & KF588365 & Italy/2013/Rovigo/32.1 & Human & Italy & 2013 \\
\hline It-11 & JN858070 & Italy/2011/AN-2 & Human & Italy & 2011 \\
\hline Au-08 & KF179640 & Austria/2008-gh & Accipiter gentilis & Austria & 2008 \\
\hline Ser-10 & KC496016 & Novi Sad-2010 & Culex pipiens & Serbia & 2010 \\
\hline Rus-07 & FJ425721 & Reb_VLG_07_H & Human & Russia & 2007 \\
\hline SA-89 & EF429197 & SPU116/89 & Human & South Africa & 1989 \\
\hline SA-01 & EF429198 & SA93/01 & Human & South Africa & 2001 \\
\hline CAR-72 & DQ318020 & ArB3573/82 & Culex tigripes & Central African Republic & 1972 \\
\hline SA-58 & EF429200 & $\mathrm{H} 442$ & Human & South Africa & 1958 \\
\hline SA-00 & EF429199 & SA381/00 & Human & South Africa & 2000 \\
\hline Mad-78 & DQ176636 & Madagascar-AnMg798 & Coracopsis vasa & Madagascar & 1978 \\
\hline
\end{tabular}

were derived from human cases, confirming the zoonotic nature of these outbreaks.

\section{MOSQUITO SPECIES ASSOCIATED WITH DISEASE TRANSMISSION: THE CASE FOR EMERGENCE IN THE UNITED KINGDOM}

Outbreaks of WNV are associated with abundant populations of mosquitoes, which can occur as a result of flooding and subsequent dry and warm weather, or formation of suitable larval breeding habitats (54). Although WNV has been isolated from over 40 species of mosquitoes, the principal mosquitoes involved in WNV transmission belong to the genus Culex, particularly species in the $C x$. pipiens complex $(55,56)$. Two species are formally recognized in the complex, Cx. pipiens (northern, temperate regions) and $C x$. quinquefasciatus (southern, tropical regions) (57). In the UK, the subgenus Culex is represented by the nominotypical Cx. pipiens (58), which include two forms, $C x$. pipiens f. pipiens and $C x$. pipiens $\mathrm{f}$. molestus. In addition, $C x$. torrentium and $C x$. europaeus are also recorded in the UK (59). These species are fairly common and widespread, with the exception of Cx. europaeus, for which few records are available. A further species, $C x$. modestus, was also believed to be rare in the UK (59). However, recent inventories of UK mosquito fauna have revealed that populations of $C x$. modestus are well established and commonly found in the North Kent marshes $(60,61)$.

The occurrence and abundance of potential vector species are a prerequisite for enzootic transmission of mosquito-borne viruses in the UK. Thirty-four species of mosquitoes have been recorded in the British Isles, of which nine species have been implicated in WNV transmission elsewhere (62). Thirteen species are likely to be bridge vectors as they readily bite both birds and humans. In Britain, the ecology of, and the potential risk of WNV transmission by, mosquito species have been detailed by several authors (62-64).

Cx. pipiens sensu stricto (s.s.) bite both humans and birds; the two forms within this species are morphologically indistinguishable, but they are physiologically different. Cx. pipiens f. pipiens is mostly ornithophagic and rarely bite humans, the immature stages are found in permanent water, it overwinters in the adult stage and is multivoltine (62). By contrast, Cx. pipiens f. molestus is highly anthropophilic (though it may bite birds), the immature stages live underground (e.g., flooded basements, sewer tunnels, underground railway systems), and all life stages occur throughout the year (63). The females can be nuisance biters in winter. Medlock et al. (64) stated that the form molestus might pose a threat for WNV transmission in suburban and rural areas. Where both forms are sympatric, hybridization can result $(65,66)$. This leads to increased numbers of mammophilic mosquitoes that can affect transmission of WNV (67). In the UK, the increased use of water containers in private gardens has also been cited as a possible factor that could lead to increases in mosquito abundance in urban areas that in turn could lead to more nuisance biting and increase the risk of WNV maintenance should it be introduced (68).

Golding et al. (60) showed that Cx. modestus accounted for $73 \%$ of all mosquito species from all sites sampled in the county of Kent and was collected in strong association with Anopheles maculipennis sensu lato (s.l.). Although the risk of WNV transmission to humans in the UK is still low due to limited human exposure to bridge vectors, the risk for transmission was higher in Kent because of the presence of other bridge vector species such as $C x$. pipiens s.l. and both migratory and resident birds. The authors highlighted the potential risk for horses, which are often grazed in this part of country. At present, screening of specimens of $C x$. modestus for WNV and other flaviviruses such as Usutu virus is being undertaken by cross-governmental groups in the UK under a "One Health" initiative.

\section{INVASIVE MOSQUITO SPECIES}

The increase in human population, expansion of trading routes and tourism, deforestation, and climate change are some of the factors that have facilitated the rapid dispersal of vector species into new geographical areas (69). Recent emergence of bluetongue virus and outbreaks of WN fever and Chikungunya fever in Europe are just a few examples of the risk of exotic vector-borne pathogens being transported to a new region (69). 
For invasive mosquitoes in Europe, six exotic species have been identified (Aedes aegypti, Ae. albopictus, Ae. atropalpus, Ae. japonicus, Ae. koreicus, and Ae. triseriatus). These have mainly been imported through the international trade in used tires and Lucky bamboo, although public and/or private ground transport have also been implicated. Of these, Ae. albopictus presents the greatest threat. Female Ae. albopictus lay desiccation-resistant eggs above the surface of the water in tree holes, tires, or other water-holding containers (70). Its ability to breed in artificial containers has facilitated its spread in recent decades along major transportation routes. Currently, Ae. albopictus is considered one of the top 100 invasive species of mosquitoes worldwide (71).

Aedes albopictus is a known vector of CHIKV, and laboratory infectious studies have shown that this species is a competent vector of WNV (72). It has been recorded in 20 European countries including the Netherlands and Belgium (its northernmost latitude) (73), although it has not been recorded in the UK. Surveillance for this and other invasive mosquito species should be a priority as their presence would radically change the risk of virus emergence.

\section{CONCLUSION}

West Nile virus lineage 2 was introduced into Europe in 2004 and subsequently emerged in a number of countries. It has overwintered in these countries and in the case of Italy is co-circulating with WNV lineage 1 and Usutu virus. Migratory birds are likely to be the main vehicle of movement for the virus, both as a source of introduction and the means by which it has spread within Europe. However, there is little direct evidence to support this. The disease manifestations appear to vary in different countries. In Hungary, raptors appear to be affected while in Greece the main burden of disease has fallen on the human population. The reasons for this are not clear, but the variation could be caused by mutations within particular virus strains that persist in different locations. The abundance and composition of mosquito populations, particularly Culex species, are critical for the spread of disease. Further study of factors such as mosquito distribution, host biting preference, and species hybridization will improve understanding of $\mathrm{WNV}$ persistence and assessment of the risk to human populations.

Following detection of WNV, there is a need to implement public health measures to protect at risk populations, particularly the elderly. This includes measures to reduce mosquito biting such as destruction of larval habitats and applications of larvicides. Measures that protect the individual include the application of mosquito repellents and clothing that reduces the exposure of bare skin. Currently, there is no human vaccine available. The risk of further spread of WNV lineage 2 to countries around the Mediterranean Sea is high. Countries in northern Europe appear to be at lower risk due to reduced mosquito abundance and lower winter temperatures. However, constant vigilance is needed to monitor for any change in environmental or ecological conditions that could make the introduction and persistence of WNV in northerly latitudes possible.

\section{AUTHOR CONTRIBUTIONS}

Nicholas Johnson conceived the idea for this review. Luis M. Hernández-Triana, Claire Jeffries, Karen Mansfield, George
Carnell, Anthony Fooks, and Nicholas Johnson prepared the manuscript. All authors read and approved the final manuscript.

\section{ACKNOWLEDGMENTS}

This study was funded by Defra, UK, through project SE4112 (Development of research tools to support arthropod-borne virus investigation) and European Union FP7 project ANTIGONE (Anticipating the Global Onset of Novel Epidemics) project number 278978.

\section{REFERENCES}

1. Kirkpatrick AM, Randolph SE. Drivers, dynamics, and control of emerging vector-borne zoonotic diseases. Lancet (2012) 380:1946-55. doi:10.1016/S01406736(12)61151-9

2. Carpenter S, Wilson A, Mellor PS. Culicoides and the emergence of bluetongue virus in northern Europe. Trends Microbiol (2009) 17:172-8. doi:10.1016/j.tim. 2009.01.001

3. Tarlinton R, Daly J, Dunham S, Kydd J. The challenge of Schmallenberg virus emergence in Europe. Vet J (2012) 194:10-8. doi:10.1016/j.tvjl.2012.08.017

4. Sambri V, Capobianchi M, Charrel R, Fyodorova M, Gaibani P, Gould E, et al. West Nile virus in Europe: emergence, epidemiology, diagnosis, treatment, and prevention. Clin Microbiol Infect (2013) 19:699-704. doi:10.1111/1469-0691. 12211

5. Smithburn KC, Hughes TP, Burke AW, Paul JH. A neurotropic virus isolated from the blood of a native of Uganda. Am J Trop Med Hyg (1940) 20:471-92.

6. Melnick JL, Paul JR, Riordan JT, Barnett VHH, Coldblum N, Zabin E. Isolation from human sera in Egypt of a virus apparently identical to West Nile virus. Proc Soc Exp Biol Med (1951) 77:661-5. doi:10.3181/00379727-77-18884

7. Work TH, Hurlbut HS, Taylor RM. Isolation of West Nile virus from hooded crow and rock pigeon in the Nile delta. Proc Soc Exp Biol Med (1953) 84:719-22. doi:10.3181/00379727-84-20764

8. Bethet F-X, Zeller HG, Drouet M-T, Rauzier J, Digoutte J-P, Deubel V. Extensive nucleotide changes and deletions within the envelope glycoprotein gene of Euro-African West Nile viruses. J Gen Virol (1997) 78:2292-7.

9. Venter M, Swanepoel R. West Nile virus lineage 2 as a cause of zoonotic neurological disease in humans and horses in southern Africa. Vector Borne Zoonotic Dis (2010) 10:659-64. doi:10.1089/vbz.2009.0230

10. Guthrie AJ, Howell PG, Gardner IA, Swanepoel RE, Nurton JP, Harper CK, et al. West Nile virus infection of Thoroughbred horses in South Africa (2000-2001). Equine Vet J (2003) 35:601-5. doi:10.2746/042516403775467180

11. Jupp PG. The ecology of West Nile virus in South Africa and the occurrence of outbreaks in humans. Ann N Y Acad Sci (2001) 951:143-52. doi:10.1111/j.17496632.2001.tb02692.x

12. Zeller HG, Schuffenecker I. West Nile virus: an overview of its spread in Europe and the Mediterranean Basin in contrast to its spread in the Americas. Eur J Clin Microbiol Infect Dis (2004) 23:147-56. doi:10.1007/s10096-003-1085-1

13. Calistri P, Giovanni A, Hubalek Z, Ionescu A, Monaco F, Savinni G, et al. Epidemiology of West Nile virus in Europe and the Mediterranean Basin. Open Virol J (2010) 4:29-37. doi:10.2174/1874357901004010029

14. Lanciotti RS, Roehrig JT, Deubel V, Smith J, Parker M, Steele K, et al. Origin of West Nile virus responsible for an outbreak of encephalitis in the northeastern United States. Science (1999) 286:2333-7. doi:10.1126/science.286.5448.2333

15. Venter M, Myers TG, Wilson MA, Kindt TJ, Paweska JT, Burt FJ, et al. Gene expression in mice infected with West Nile virus strains of different neurovirulence. Virology (2005) 342:119-40. doi:10.1016/j.virol.2005.07.013

16. Venter M, Human S, Zaayman D, Gerdes GH, Williams J, Steyl J, et al. Lineage 2 West Nile virus as cause of fatal neurological disease in horses, South Africa. Emerg Infect Dis (2009) 15:877-84. doi:10.3201/eid1506.081515

17. Zaayman D, Venter M. West Nile virus neurologic disease in humans, South Africa, September 2008 - May 2009. Emerg Infect Dis (2012) 18:2051-4. doi:10.3201/eid1812.111208

18. Chaintoutis SC, Chaskopoulou A, Chassalevris T, Koehler PG, Papanstassopoulou M, Dovas CI. West Nile virus lineage 2 strain in Greece, 2012. Emerg Infect Dis (2013) 19:827-9. doi:10.3201/eid1905.121418

19. Lanciotti RS, Ebel GD, Deubel V, Kerst AJ, Murri S, Meyer R, et al. Complete genome sequences and phylogentic analysis of West Nile virus strains isolated from the United States, Europe, and the Middle East. Virology (2002) 298:96-105. doi:10.1006/viro.2002.1449 
20. Sotelo E, Fernández-Pinero J, Llorente F, Vázquez A, Moreno A, Agüero $\mathrm{M}$, et al. Phylogenetic relationships of Western Mediterranean West Nile virus strains (1996-2010) using full-length genome sequences: single or multiple introductions. J Gen Virol (2011) 92:2512-22. doi:10.1099/vir.0. 033829-0

21. Bakonkyi T, Ivanics E, Erdélyi K, Ursu K, Ferenczi E, Weissenböck H, et al. Lineage 1 and 2 strains of encephalitic West Nile virus, Central Europe. Emerg Infect Dis (2006) 12:618-23. doi:10.3201/eid1204.051379

22. Platanov AE, Karan LS, Shopenskaia TA, Fedorova MV, Koliasnikova NM, Rusakova NM, et al. Genotyping of West Nile fever virus strains circulating in southern Russia as an epidemiological investigation method: principles and results. Zh Mikrobiol Epidemiol Immunobiol (2011) 2:29-37.

23. Bakonyi T, Ferenczi E, Erdélyi K, Kutasi O, Csörgo T, Seidel B, et al. Explosive spread of a neuroinvasive lineage 2 West Nile virus in Central Europe. Vet Microbiol (2013) 165:61-70. doi:10.1016/j.vetmic.2013.03.005

24. Wodak E, Richter S, Bagó Z, Revilla-Fernández S, Weissenböck H, Nowotny $\mathrm{N}$, et al. Detection and molecular analysis of West Nile virus infections in birds of prey in the eastern part of Austria in 2008-2009. Vet Microbiol (2011) 149:358-66. doi:10.1016/j.vetmic.2010.12.012

25. Papa A, Xanthopoulou K, Gewehr S, Mourelatos S. Detection of West Nile virus lineage 2 in mosquitoes during a human outbreak in Greece. Clin Microbiol Infect (2011) 17:1176-80. doi:10.1111/j.1469-0691.2010.03438.x

26. Sirbu A, Ceianu CS, Panculescu-Gatej RI, Vázquez A, Tenorio A, Rebeanu R, et al. Outbreak of West Nile virus infection in humans, Romania, July to October 2010. Euro Surveill (2011) 16:19762.

27. Bagnarelli P, Marinelli K, Trotta D, Monachetti A, Tavio M, Del Gobbo R, et al. Human case of autochthonous West Nile virus lineage 2 infection in Italy, September 2011. Euro Surveill (2011) 16:20002.

28. Magurano F, Remoli ME, Baggieri M, Fortuna C, Marchi A, Fiorentini C, et al. Circulation of West Nile virus lineage 1 and 2 during an outbreak in Italy. Clin Microbiol Infect (2012) 18:E545-7. doi:10.1111/1469-0691.12018

29. Savini G, Puggioni G, Di Gennaro A, Di Francesco G, Rocchigiani AM, Polci A, et al. West Nile virus lineage 2 in Sardinian wild birds in 2012: a further threat to public health. Epidemiol Infect (2013) 141:2313-6. doi:10.1017/ S0950268812003147

30. Popović N, Miloševic B, Uroševic A, Poluga J, Lavadnović L, Nedelijković J, et al. Outbreak of West Nile virus infection among humans in Serbia, August to October 2012. Euro Surveill (2013) 18:260613.

31. Barzon L, Pacenti M, Franchin E, Lavezzo E, Masi G, Squarzon L, et al. Whole genome sequencing and phylogenetic analysis of West Nile virus lineage 1 and lineage 2 from human cases of infection, Italy, August 2013. Euro Surveill (2013) 18:20591.

32. Papa A, Danis K, Baka A, Bakas A, Dougas G, Lytras T, et al. Ongoing outbreak of West Nile virus infections in humans in Greece, July - August 2010. Euro Surveill (2010) 15:19644.

33. Papa A, Perperidou P, Tzouli A, Castilletti C. West Nile virus-neutralising antibodies in humans in Greece. Vector Borne Zoonotic Dis (2010) 10:655-8. doi:10.1089/vbz.2010.0042

34. Danis K, Papa A, Theocharopoulos G, Dougas G, Athanasiou A, Detsis M, et al. Outbreak of West Nile virus infection in Greece, 2010. Emerg Infect Dis (2011) 17:1868-72. doi:10.3201/eid1710.110525

35. Papa A, Xanthopoulou K, Tsioka A, Kalaitzopoulou S, Mourelatos S. West Nile virus in mosquitoes in Greece. Parasitol Res (2013) 112:1551-5. doi:10.1007/ s00436-013-3302-x

36. Valiakos G, Touloudi A, Athanasiou LV, Giannakopoulos A, Iacovakis C, Birtas $\mathrm{P}$, et al. Serological and molecular investigation into the role of wild birds in the epidemiology of West Nile virus in Greece. Virol J (2012) 9:266. doi:10.1186/1743-422X-9-266

37. Barzon L, Papa A, Pacenti M, Franchin E, Lavezzo E, Squarzon L, et al. Genome sequencing of West Nile virus from human cases in Greece, 2012. Viruses (2013) 5:2311-9. doi:10.3390/v5092311

38. Savini G, Capelli G, Monaco F, Polci A, Russo F, Di Gennaro A, et al. Evidence of West Nile virus lineage 2 circulation in Northern Italy. Vet Microbiol (2012) 158:267-73. doi:10.1016/j.vetmic.2012.02.018

39. Petrović T, Blázquez AB, Lupulović D, Lazić G, Escribano-Romero E, Fabijan $\mathrm{D}$, et al. Monitoring West Nile virus (WNV) infection in wild birds in Serbia during 2012: first isolation and characterisation of WNV strains from Serbia. Euro Surveill (2013) 18:20622.
40. Cnops L, Papa A, Lagra F, Weyers P, Meersman K, Patsouros N, et al. West Nile virus infection in Belgian traveler returning from Greece. Emerg Infect Dis (2013) 19:684-5. doi:10.3201/eid1904.121594

41. Rappole JH, Derrickson SR, Hubálek Z. Migratory birds and spread of West Nile virus in the Western Hemisphere. Emerg Infect Dis (2000) 6:319-27. doi:10.3201/eid0604.000401

42. Rappole JH, Hubálek Z. Migratory birds and West Nile virus. J Appl Microbiol (2003) 94:47S-58S. doi:10.1046/j.1365-2672.94.s1.6.x

43. Gale P, Johnson N. The role of birds in the spread of West Nile virus. In: Johnson $\mathrm{N}$, editor. The Role of Animals in Emerging Viral Diseases. San Diego, CA: Elsevier (2013). p. 143-67.

44. Jourdain E, Gauthier-Clerc M, Bicout DJ, Sabatier P. Bird migration routes and risk for pathogen dispersion into Western Mediterranean wetlands. Emerg Infect Dis (2007) 13:365-72. doi:10.3201/eid1303.060301

45. Engler O, Savini G, Papa A, Figuerola J, Groschup MH, Kampen H, et al. European surveillance for West Nile virus in mosquito populations. Int J Environ Res Public Health (2013) 10:4869-95. doi:10.3390/ijerph10104869

46. Petersen LR, Marfin AA. West Nile virus: a primer for the clinician. Ann Intern Med (2002) 137:173-9. doi:10.7326/0003-4819-137-3-200208060-00009

47. Petersen LR, Roehrig JT, Hughes JM. West Nile virus encephalitis. N Engl J Med (2002) 347:1225-6. doi:10.1056/NEJMo020128

48. Rossi SL, Ross TM, Evans JD. West Nile Virus. Clin Lab Med (2010) 30:47-65. doi:10.1016/j.cll.2009.10.006

49. Mostashari F, Bunning ML, Kitsutani PT, Singer DA, Nash D, Cooper MJ, et al. Epidemic West Nile encephalitis, New York, 1999: results of a householdbased seroepidemiological survey. Lancet (2001) 358:261-4. doi:10.1016/S01406736(01)05480-0

50. Anastasiadou A, Kakoulidis I, Butel D, Kehagia E, Papa A. Follow-up study of Greek patients with West Nile virus neuroinvasive disease. Int J Infect Dis (2013) 17:e494-7. doi:10.1016/j.ijid.2012.12.006

51. Brault AC, Huang CYH, Langevin SA, Kinney RM, Bowen RA, Ramey WN, et al. A single positively selected West Nile viral mutation confers increased virogenesis in American crows. Nat Genet (2007) 39:1162-6. doi:10.1038/ng2097

52. Capelli G, Ravagnan S, Montarsi F, Ciocchetta SC, Bonfanti L, Di Gennaro A, et al. Further evidence of lineage 2 West Nile Virus in Culex pipiens of NorthEastern Italy. Vet Ital (2013) 49:263-8. doi:10.12834/VetIt.1304.02

53. Bakonyi T, Hubalek Z, Rudolf I, Nowotny N. Novel flavivirus or new lineage of West Nile virus, Central Europe. Emerg Infect Dis (2005) 11:225-31. doi:10.3201/eid1102.041028

54. Hubálek Z. European experience with the West Nile virus ecology and epidemiology: could it be relevant for the New World? Viral Immunol (2000) 13:415-26. doi:10.1089/vim.2000.13.415

55. Crook PD, Crowcroft NS, Brown DWG. West Nile virus and the threat to the UK. Commun Dis Public Health (2002) 5:138-43.

56. Higgs S, Snow K, Gould EA. The potential for West Nile virus to establish outside of its natural range: a consideration of potential mosquito vectors in the United Kingdom. Trans R Soc Trop Med Hyg (2004) 98:82-7. doi:10.1016/S0035-9203(03)00004-X

57. Fonseca DM, Keyghobadi N, Malcolm CA, Mehmet C, Schaffner F, Mogi M, et al. Emerging vectors in the Culex pipiens complex. Science (2004) 303:1535-8. doi:10.1126/science. 1094247

58. Harbach RE, Dahl C, White GB. Culex (Culex) pipiens Linnaeus (Diptera: Culicidae): concept, type, designations, and description. Proc Entomol Soc Wash (1985) 87:1-24.

59. Medlock JM, Snow KR, Leach S. Potential transmission of West Nile virus in the British Isles: an ecological review of candidate mosquito bridge vectors. Med Vet Entomol (2005) 19:2-21. doi:10.1111/j.0269-283X.2005.00547.x

60. Golding N, Nunn M, Medlock JM, Purse BV, Vaux GC, Schäffer SM. West Nile virus vector Culex modestus established in southern England. Parasit Vectors (2012) 5:32. doi:10.1186/1756-3305-5-32

61. Medlock JM, Vaux AGC. Distribution of West Nile vector, Culex modestus, in England. Vet Rec (2012) 171:278. doi:10.1136/vr.e6123

62. Medlock JM, Snow KR, Leach S. Possible ecology and epidemiology of medically important mosquito-borne arboviruses in Great Britain. Epidemiol Infect (2007) 135:466-82. doi:10.1017/S0950268806007047

63. Gould EA, Higgs S, Buckely A, Gritsun TS. Potential arbovirus emergence and implications for the United Kingdom. Emerg Infect Dis (2006) 4:549-55. doi:10.3201/eid1204.051010 
64. Medlock JM, Jameson LJ. Ecological approaches to informing public health policy makers and risk assessments on emerging vector-borne zoonoses. Emerg Health Threats J (2010) 3:e1. doi:10.3134/ehtj.10.001

65. Gomes B, Sousa CA, Vincente JL, Pinho L, Calderón I, Arez E, et al. Feeding patterns of molestus and pipiens forms of Culex pipiens (Diptera: Culicidae) in a region of high hybridization. Parasit Vectors (2013) 6:93. doi:10.1186/17563305-6-93

66. Gomes B, Kioulos E, Papa A, Almeida AP, Vontas J, Pinto J. Distribution and hybridization of Culex pipiens forms in Greece during the West Nile virus outbreak of 2010. Infect Genet Evol (2013) 16:218-25. doi:10.1016/j.meegid.2013. 02.006

67. Ciota AT, Chin PA, Kramer LD. The effect of hybridization of Culex pipiens complex mosquitoes on transmission of West Nile virus. Parasit Vectors (2013) 6:305. doi:10.1186/1756-3305-6-305

68. Townroe S, Callaghan A. British container breeding mosquitoes: the impact of urbanization and climate change on community composition and phenology. PLoS One (2014) 9:e95325. doi:10.1371/journal.pone.0095325

69. Singh S. Viral Infections and Global Change. Hoboken, NJ: John Wiley and Sons (2014). 659 p.

70. Medlock JM, Hansford KM, Schaffner F, Versteirt V, Hendrickx G, Zeller $\mathrm{H}$, et al. A review of the invasive mosquitoes in Europe: ecology, public health risks, and control options. Vector Borne Zoonotic Dis (2012) 12:435-47. doi:10.1089/vbz.2011.0814

71. Benedict MQ, Levine RS, Hawley WA, Lounibos LP. Spread of the Tiger: global risks of invasion by the mosquitoes Aedes albopictus. Vector Borne Zoonotic Dis (2007) 7:76-85. doi:10.1089/vbz.2006.0562
72. Sardelis MR, Turell MJ, O'Guinn ML, Andre RG, Roberts DR. Vector competence of three North American strains of Aedes albopictus for West Nile virus. $J$ Am Mosq Control Assoc (2002) 18:284-9.

73. Scholte EJ, Den Hartog W, Schoelitsz B, Brooks M, Schaffner F, Foussadier R, et al. Introduction and control of mosquitoes of three invasive species in the Netherlands, July-October 2010. Euro Surveill (2010) 15:19710.

Conflict of Interest Statement: The authors declare that the research was conducted in the absence of any commercial or financial relationships that could be construed as a potential conflict of interest.

Received: 30 June 2014; accepted: 23 November 2014; published online: 08 December 2014.

Citation: Hernández-Triana LM, Jeffries CL, Mansfield KL, Carnell G, Fooks AR and Johnson N (2014) Emergence of West Nile virus lineage 2 in Europe: a review on the introduction and spread of a mosquito-borne disease. Front. Public Health 2:271. doi: 10.3389/fpubh.2014.00271

This article was submitted to Epidemiology, a section of the journal Frontiers in Public Health.

Copyright @ 2014 Hernández-Triana, Jeffries, Mansfield, Carnell, Fooks and Johnson. This is an open-access article distributed under the terms of the Creative Commons Attribution License (CC BY). The use, distribution or reproduction in other forums is permitted, provided the original author(s) or licensor are credited and that the original publication in this journal is cited, in accordance with accepted academic practice. No use, distribution or reproduction is permitted which does not comply with these terms. 